Middle Eastern affairs, is the account by Fauziah Mohamad Taib (chapter 28, "The Day the World Changed", pp. 257-69), who had been Deputy Chief of Mission in Washington DC from 1998 to 2003, on the September 11, 2001 terrorist attacks on the World Trade Center in New York City, seen through her own eyes. Similarly moving are the stories by Dato' K.N. Nadarajah, Malaysian ambassador to Iraq from 1986 to 1991 (chapter 27, "Gulf Crisis: Evacuation of Malaysians”, pp. 247-55), and especially by Tan Sri Ahmad Fuzi Abdul Razak, previously Director General of IDFR and currently Ambassador-at-Large for Foreign Affairs (chapter 21, "An Encounter with Saddam Hussein”, pp. 193-201). Very valuable, too, are the insights provided by Datin Paduka Dr Rajmah Hussain, who currently serves as Malaysia's first female ambassador to the United States (chapter 29, "Reflections of a Lady Diplomat”, pp. 271-81). The fact that Sharifah Shifa Al-Attas, IDFR's Director of Research and Publication (who already has a reputation as one of Malaysia's most distinguished editors) has been behind the design of the volume's cover and layout has ensured that this book is also from an aesthetical and artistic point of view such a delight.

In sum, however, Number One Wisma Putra is not just a beautiful book that should not be missing on the shelves of those who want to know what it meant to create from scratch an efficient foreign ministry. It will also be treasured by those who want to know more about the key players, their often turbulent experiences and adventures - be it as foreign minister or as ambassadors. It is thus a fitting tribute to and celebration of the achievements and hard work that led to what Wisma Putra is today - a worldwide respected institution with now 102 diplomatic missions around the globe of a country that is also making a steadily increasing impact as a bridge between Asia and the West.

\title{
David Levering Lewis - God's Crucible: Islam and the Making of Europe, 570-1215
}

(New York and London: W.W. Norton, 2009), paperback, xxv +473 pp. ISBN 978-0-393-06472-8, US\$17.95

\section{Karim D. Crow IAIS Malaysia}

God's Crucible marks Lewis' historical engagement with the major theme of the impact of Islamic civilisation upon the formation of Europe. Through his synthesis of secondary historical studies in English, French and Spanish Lewis paints a broad historical canvas portraying the rise and spread of Islam in South West Asia, its dramatic extension across North Africa into the Iberian peninsula and beyond under the Umayyad Caliphs, and the complex interaction and vicissitudes of Christian and Muslim powers in Hispania/Andalusia. He ends his narrative with the start of 
the reconquista at the fateful Battle of Las Navas de Tolosa in 1212, which was fought not far from Toledo in central Spain and which ended with the total victory of the combined forces of three Christian kings of Castile, Aragon, and Navarra over the Almohad caliph Muhammad III (r. 1199-1213): "the first war fought by Christians and Muslims exclusively as Muslims and as Christians - a war between civilizations" (p. 378). Lewis clearly has the contemporary 'clash' in mind when exploiting this much abused phrase.

Lewis is a distinguished scholar of comparative history (University Professor) now teaching at New York University, twice winner of the Pulitzer Prize for his two-volume biography of W.E.B. Du Bois, and a past president of the Society of American Historians. The range of his competence includes the late-nineteenthcentury conflict between British imperialism and Muslim reassertion, a biography of Martin Luther King, and a history of anti-Semitism in France with the Dreyfus affair at its centre. For a historian hitherto concerned chiefly with the modern period, to undertake a detailed synopsis of Islam's unfolding over its first half-millennium and the amazing presence it established in southwest Europe - without previous training in Arabic or Iberian studies - shows both intellectual curiosity and courage. Fortunately, there now exist enough basic Arabic sources in translation (Ibn Ishāăq, Ṭabarī, Mas 'ūdī [in French trans.], Maqqārī, Ghazālī, Ibn Rushd, Ibn Khaldūn) along with solid surveys and monographs on specific topics and periods, that an American historian may approach the classical age of Islam with a measure of credibility.

It is gratifying to see Lewis insisting on employing 'Common Era' (CE) dating - instead of the Christian-derived AD - and recognising that historical objectivity requires one to match significant European dates with their Islamic era hijrah equivalents ( $\mathrm{AH}$ ) - thus the Umayyad conquest of Visigothic Hispania occurred in $711 \mathrm{CE}=92 \mathrm{AH}$ (i.e. 78 solar years after the death of the Prophet Muhammad). In his preliminary 'Notes on Usage' Lewis correctly observes (p. xix):

The time is fast approaching when Arabic names and terms, unfamiliar and difficult though they are to people formed by Western culture, should be reproduced in historical works intended for a wide readership avid for information and understanding precisely as they are written in Standard Arabic with their diacritical notations.

But his editors' preference must have intervened, for he next states: "diacritical marks have been omitted in the transliteration from Arabic" - even while he employs many Latin, Greek and Spanish terms deemed essential for purposes of his narrative.

And what a narrative does Lewis pour out of his wide reading and digestion of a rich pastiche of scholarship - a veritable exhilarating jaunt through the centuries at a speedy clip! Intending on serving up a piquant meal 'for a wide readership', he dwells in some detail upon certain key events and battles shaping the course of history: from the penetration of Hispania in 711 by Țāriq b. Ziyād (governor 
of Tangier under Mūsā b. Nuṣayr the Umayyad viceroy of Ifrīqīyah, what was formerly the Roman province of Africa, roughly corresponding to modern Tunisia and the eastern parts of Algeria), the 'myth' of the battle of Poitiers (chap. 7), and the "Carolingian Jihads" with the fundamental role exerted by the Song of Roland in forging the European sense of self and of otherness (chap. 11). One frequently gets the impression that Lewis is trying too hard to make his dense fact-filled prose more digestible and absorbing by choosing adjectives, snappy popular images and idiomatic turns of phrase to lighten up his narrative (p. 370: "The Toledo conveyor belt delivered a volume of translated data that significantly lifted the cultural level of the West"). His narrative is history popularised for the educated 'western' readership, and there is a real need for such vulgarisation in our era when voices assert the inevitability of 'war between civilizations'.

Lewis uncovers nothing new which others have not previously examined. His gift is that of synthesis and presentation wrapped in a stimulating recounting, peppered with his own judgments and hypotheses. Comparing Lewis' bestselling work with the earlier solid historical study by Norman Daniel, The Arabs and Mediaeval Europe, ${ }^{1}$ who covered much the same civilisational ground as Lewis does, yet who paid more attention to Central and Western Mediterranean regions besides Andalusia, as well as to the cultural and scientific factors. One regrets Lewis' inexperience with western Islamic studies, sometimes being misled by his secondary sources to commit elementary errors (which a competent editorial staff could have prevented). We may mention here several errors, not to detract from Lewis' achievement, but to caution readers they are being treated to a tertiary presentation which may inadvertently distort.

In his second chapter Lewis describes the Zamzam well (in the near vicinity of the Ka 'bah in the centre of Mecca) as "a few miles outside the city" (p. 31); the Prophet Muhammad's youngest daughter Fātimah becomes "his eldest daughter" (p. 52), and on the same page the first Caliph Abū Bakr died "from natural causes" whereas sound Muslim tradition records Abū Bakr died of poison. When recounting the Prophet's participation in the rebuilding of the $\mathrm{Ka}$ ' $\mathrm{bah}$ five years before the start of his mission, Lewis writes (p. 32): “At age thirty-five, we see fairly prominent Meccan Muhammad pitching in physically to help raise the $K a$ ' $b a h$ walls and spruce up the numerous fetishes and minor deities surrounding the structure." As far as I am aware, there is absolutely no mention of any such 'sprucing up' by the merchant Muhammad of the idols surrounding the $K a$ ' $b a h^{2}$ in early Arabic sources! What is stressed and often repeated in Muslim sources is Muhammad's crucial assistance in resolving the dispute among his clansmen through helping to remount the sacred 'Black Stone' into the wall of this venerable structure. This kind of gratuitous projection on Lewis' part tends to undermine confidence in some of the hypotheses 
he proffers over the course of his narrative, displaying his tendency to sacrifice accuracy and attention to detail for the sake of his grand sweeping narrative.

In his important final chapter on the intellectual achievements of al-Andalus and its legacy for the emergence of the European mind (pp. 367-79), entitled "Knowledge Transmitted, Rationalism Repudiated: Ibn Rushd and Mūsā b. Maymūn”, Lewis commits factual and interpretive errors regarding the proper assessment of the centrality of rationality in Islam. Referring to Muslim philosophers Lewis opines (p. 368): "The signature of Arabic philosophy (falsafa) was synthesis and commentary whose prototype came with the Persian-inflected writings of Ya 'qub ibn Ishaq al-Kindi during the middle of the ninth century." Now, quite apart from characterising Islamic philosophy as concerned primarily with "synthesis and commentary" (which might be an accurate description of Hellenic philosophy in late antiquity), to portray al-Kindī's writings as "Persian-inflected" is mistaken, since he was a pure Arab descended from the tribe of Kindah based in lower Iraq, frequently referred to afterwards as the 'philosopher of the Arabs'. The greatness of al-Kindī and his profound contribution to the advancement of human thought through the circle of scholar-translators he promoted and patronised under Abbasid rule, is only today becoming apparent through studies by G. Endress, R. Rashid, and others.

Lewis pays attention to Ibn Rushd (the Averroës of the medieval Latin West), whose massive impact upon the Latins continues to reverberate today, and who is credited with having helped craft the Almohad Creed ('aqìdah) issued by caliph Abū Ya 'qūb Yūsuf in 1183 - rightly described by Lewis as (p. 373): "a triumph of rationalism mobilized in support of qur'ānic authority". But Lewis curiously portrays him as (p. 372) "the greatest exponent of a modified Mu 'tazilism" whose Aristotelian philosophic doctrines (e.g., the heavens were created in time) "betrayed dangerous Mu'tazilite ideas". This again appears to be a case of being misled by secondary sources, or of his too casual and hurried reading. In truth, one cannot fault Lewis here for conflating the peripatetic strain of Islamic philosophic rationality with the theological school of $\mathrm{Mu}$ 'tazilite speculative reason, since this unwarranted confusion still remains a commonplace within the secondary literature and still today is deemed by many as conventional wisdom. This old misunderstanding was fostered by Occidental scholars who studied Islam in the late nineteenth and early twentieth centuries. ${ }^{3}$ Ironically, this error was much earlier intentionally perpetrated as a slander by hadith-based Traditionalist Muslim authorities often suspicious of too wide a scope awarded rationality within religious thought. The Mu'tazilites were the first major orthodox theological school in Islam for several centuries under the Abbasids, and actively opposed Hellenic philosophic doctrines - they certainly never held that the heavens were temporally created! To blame them for the sins of the Greeks (reason vs. revelation) is a fallacy, and it would be best to discard this old canard. 
The thrust of this well written book brimming with battles, caliphs and kings, and insights into the cultural and intellectual formation of early medieval Europe, is that Europe's rise would not have been possible without the civilisational fertilisation which Islamic presence in Andalusia bestowed. In an interesting convergence with the thesis presented 30 years ago by the reputable Tunisian thinker Hichem Djaït, ${ }^{4}$ Lewis confirms that the history of modern Europe (and by extension, the globalised Euro-American system now in place) was brought about in large part as a reaction to Islam. This realisation may serve as a starting point for re-thinking the civilisational needs of Muslim societies now dominated by a powerful mercantile and military 'West'.

\section{Notes}

1. N. Daniel, The Arabs and Mediaeval Europe (London and New York: Longman, and Beirut: Librairie du Liban, 1979, 2nd ed.); the third of Daniel's great trilogy on the historical unfolding of mutual perceptions between Islam and Europe, that began with his classic Islam and the West: The Making of an Image (Edinburgh: Edinburgh University Press, 1960). Daniel exploited the original Latin and Arabic sources and made major contributions to our understanding of the reciprocal engagement between pre-modern Europe and Islam. Interestingly, Lewis ignores Daniel's work.

2. To be precise: 360 stone posts or 'idols' ringing the cubic centre, since the $\mathrm{Ka}$ ' $\mathrm{bah}$ in most ancient times functioned as a solar calendrical device akin to Stonehenge and similar structures extant across Europe and North America. Few Muslims realise this today, of course.

3. Lewis makes clear his dependence on Orientalist discourse when he twice approvingly cites (pp. 374 and 421 n.17) the tribute paid to Ibn Rushd's great influence in thirteenth-century Christian Europe on the authority of that great doyen of neo-Thomist Catholic intellectuals, Etienne Gilson: "Rationalism was born in Spain in the mind of an Arabian philosopher as a conscious reaction against the theologism of the Arabian divines." Lewis here cites E. Gilson's Reason and Revelation in the Middle Ages (1938). See also Majid Fakhry, Averroes: His Life, Works and Influence (Oxford: Oneworld, 2001), xv-xvi.

4. Hichem Djaït [Ja'ît], Europe and Islam: Cultures and Modernity, trans. P. Heinegg (Berkeley CA: University of California Press, 1985) - a work that still merits reading today.

\section{Umer Chapra - Muslim Civilization: The Causes of Decline and the Need for Reform}

(Leicester, United Kingdom: The Islamic Foundation, 2008), paperback, xxii +225 pp. ISBN: 978-0-86037-4619, £13

\section{Ibrahim Umar University of Leicester, United Kingdom}

Chapra's book comes at a time when it is most needed. This is an era of upheavals and attempts at 'revivalism' in the Muslim communities and countries across the world. Chapra examines the factors responsible for the decline in Muslim civilisation and tries to offer suggestions on alternative routes for the Muslim world to regain its rightful position among the world's civilisations. 